\title{
The Effect of Motivation and Leadership on Performance Through Productive Behavior
}

\section{Muhdar $^{1 *}$, Bagus $^{2}$, Supardi $^{3}$}

1,2,3 STIE Mandala Jember

\section{A R T I C L E I N F O}

Article history:

Received 25 August 2018

Received in revised form

02 October 2018

Accepted 20 October 2018

Available online 29

November 2018

Keywords:

Motivation, Leadership, and

Productive Performance

\begin{abstract}
A B S T R A CT
This study is intended to analyze the influence of motivation and leadership on performance through productive behavior of case studies on Civil Servants (PNS) teachers in Kalibaru State Vocational School. The type of data used is primary data, obtained by interviewing and distributing questionnaires to the population of all Civil Servants teachers in the Kalibaru State Vocational School in amount 38 people. By using regression analysis, the results are obtained: (1). Motivation has a positive and significant influence on productive behavior, (2). Leadership has a positive and significant influence on performance, (3). Motivation has a positive and significant effect on performance through productive behavior, (4). Leadership has an influence on the performance of PNS teachers in Kalibaru State Vocational School, and (5). Productive behavior has an influence on the performance of PNS teachers in Kalibaru State Vocational School. From the results of the study it is expected that schools and principals pay more attention to and improve services to PNS teachers in motivating and leading teachers and providing positive behavior so that PNS teachers can work well, responsibly, comfortably and are able to improve school goals in accordance with the school's vision and mission.
\end{abstract}

\footnotetext{
* Corresponding author.

E-mail addresses: yesmuhdar@gmail.com (Muhdar),
} 


\section{Introduction}

In the era of ASEAN economic society (MEA), the readiness of human resources is needed because competitors are not only from domestic but also from other countries that will enter the country of Indonesia. The competition is varying from economic, political, social cultural, scientific and technological aspects. With increasing competitiveness, the government initiated the Nawa Cita program to lead Indonesia to be politically sovereign and independent in the fields of economy and personality in culture. The fifth Nawa Cita is to improve the quality of Indonesian human life through improving the quality of education and training with the "Indonesia Pintar" program; as well as improving the welfare of the community with the "Indonesia Kerja" and "Indonesia Sejahtera" program by encouraging 9-hectare land reform and land ownership programs, series of village house programs or subsidized low-cost apartments and social security for the people in 2019.

With the density of the Indonesian population, the need for improving the quality of education and debriefing skills on human resources starts from the secondary to tertiary level. Education is important not only for children, but everyone also needs education. It can be obtained at school or other non-formal education organizations. Whatever education is taken is basically an effort to increase someone's knowledge from not knowing to knowing and understanding. The quality of education is very dependent on the education program implemented. Furthermore, the quality of education can be obtained if the teaching staff really can implement the education program properly. To make our country is not inferior to neighbor countries of course the government must improve the quality of education that exists. Education in Indonesia is still classified as middle and lower because of inadequate systems and facilities.

Improving the quality of education strived for improvement in teacher performance and innovation should always be developed. According to performance is a translation of the word performance which is defined as the result or overall success of a person over a period of time compared to various possibilities, such as standard results work, target or criteria that have been determined in advance and have been agreed upon. Opinion about the performance of the teacher mentioned above is in line with Mangkunegara, who states that performance (work performance) is the work in quality and quantity achieved by an employee in carrying out his duties in accordance with the responsibility given to him. Factors that influence the performance of a teacher can come from within the individual itself such as motivation, skills, and also education. There are also external factors such as work climate, salary level, etc. According to Porter et al., Filak \& Sheldon teacher work motivation is very important for the performance and success of each education system. Meanwhile, a research of Pratiwi (2013) founds that motivation affects teacher performance and principal leadership, according to teacher perceptions, has influence on teacher performance.

The problems faced by teachers and employees at Kalibaru State Vocational School in Banyuwangi is about motivation and leadership towards productive behavior that affect performance, because productive behavior is very necessary to measure the performance of teachers and employees towards the responsibilities given. Productive behavior is an important factor in contributing to the performance of civil servant (PNS) teachers at Kalibaru State Vocational School, because productive behavior can measure how well teachers and employees are at school. Besides the productive behavior of the performance of teachers and employees, it is also influenced by the motivation of PNS teacher in Kalibaru State Vocational School. Work motivation must get more serious attention because it can measure how much encouragement from inside and outside the school. It is realized that low motivation also affects low productive behavior. Aside from the above, it is also important that leadership is also expected to influence the performance of PNS teachers in Kalibaru State Vocational School.

Based on the problems and descriptions above, the study entitled "The Effect of Motivation and Leadership on Performance through Productive Behavior (study on PNS Teachers in Kalibaru Public Vocational School)" was implemented

\section{Methods}

This research was conducted at Kalibaru Banyuwangi Vocational School, in the even semester of the academic year 2017/2018. While the time of the research was carried out according to the lesson schedule set by the School.

The research that only examines a portion of the population is called sample research. According to the sample is "part of the population". The population is for example residents in certain regions, number of employees in certain organizations, number of teachers and students in certain schools and so on. Meanwhile, Margono (2010: 121) suggests that the sample is "as part of the population, for example 
(monster) taken using certain methods". In line with that, suggests that the sample is "partially taken from the population". Based on some expert opinions, the authors conclude that the sample is part of the population taken.

Saturation sampling is a sample that represents the population. It is commonly applied if the population is considered small or less than 100. Determining the population in a study is very significant, with the aim to make easier and facilitate a study that will be carried out. This research was conducted at Kalibaru State Vocational School. The number of teachers and employees in the Kalibaru Vocational School has the status of civil servants and non-permanent teachers (GTT) and temporary employees (PTT). The populations in this study were all PNS teachers at Kalibaru State Vocational School in Banyuwangi who were numbered 38 people as respondents. The sampling technique is census sample which means that all populations are used as samples.

This study used three variables, namely the independent variable which are Motivation (X1) and Leadership (X2) and the dependent variable, which is Performance (Y2). While the intervening variable in this study is productive behavior (Y1).

Based on the identification of variables, the following explains the operational definition of research variables namely Motivation $\left(\mathrm{X}^{1}\right)$, According to Porter et al., Filak \& Sheldon teacher work motivation is very important for the performance and success of each education system. Teacher work motivation is an encouragement that moves and influences the teacher to carry out their duties and responsibilities well in accordance with the intended purpose. According to Cave and Mulloy teachers who have high work motivation will always develop professionalism and innovative programs to improve student learning. Thus it can be concluded that teacher work motivation is an encouragement for teachers to carry out their duties and responsibilities. According to the factors that influence individual work motivation as well as indicators in motivational variables, are a) A sense of security, which is the certainty of obtaining a permanent job, holding a position in the organization during maybe as they expected, b) Opportunities to advance, that is the possibility of advancing, rising levels, gaining position and expertise; c) Type of work, that is the existence of work that is suitable with educational background, experience, talents, and interests; d) A good place to work, that is a company (school) that gives employees pride when they work in the company or school; e) Colleagues, those are colleagues who agree and are suitable for cooperation; f) Wages, namely income received; g) Supervisors, those are leaders or superiors who have good relations with their subordinates, and consider opinions expressed by their subordinates; h) Working hours, those are regular or certain working hours in a day; i) Working conditions, condition such as cleanliness of the workplace, temperature, work space, ventilation, noise, smell, and so on.

Toward leadership variables $\left(\mathrm{X}^{2}\right)$, Hersey and Blanchard argue that: "Leadership is the process of influencing someone or group's activities to achieve goal in certain situation". Some indicators in leadership are 1). Posses an ability to exceed others. 2). Posses a great sense of responsibility. 3). Willing to work hard. 4). Sociable. 5). Give examples to work with enthusiasm for subordinates. 6). Have a sense of integrity. The dependent variable in this study is Performance $\left(\mathrm{Y}^{2}\right)$. Performance is the result of work that can be achieved by a person or group of people in an organization in accordance with their respective authorities and responsibilities in an effort to achieve organizational goals legally, do not violate the law and do not conflict with morals or ethics. The indicator used in Performance uses an assessment from namely: 1). Harmonious relationship, 2). Job satisfaction 3). Work climate, 3). Benefit. 4). Satisfaction in return. 5). Peace of soul. Intervening variables in this study are productive behavior $\left(\mathrm{Y}^{1}\right)$. Productive behavior is the behavior of employees who give positive contribution to the goals and objectives of the organization. Intervening variable is Productive Behavior consisting of the following indicators 1). Job performance, 2). Organizational behavior (organizational citizenship behavior abbreviated as OCB), 3). Innovation and creativity (Jex and Britt, 2008).

The data collection method in this study was carried out using the questionnaire method, interview and literature study. Data analysis methods include validity and reliability test, path analysis, econometrics evaluation or classic assumption test (normality test, multicollinearity test and heteroscedasticity test), model suitability test and path calculation.

\section{Result and Discussion}

The results of the research analysis are presented in the table as follows:

Table 1. Direct influence path coefficient 


\section{Correlations}

\begin{tabular}{|ll|r|r|r|r|}
\hline & & Motivasi & $\begin{array}{r}\text { Kepemimpina } \\
\mathrm{n}\end{array}$ & $\begin{array}{r}\text { Perilaku_Prod } \\
\text { uktif }\end{array}$ & \multicolumn{1}{c|}{ Kinerja } \\
\hline Motivasi & Pearson Correlation & 1 &, $583^{\prime \prime \prime}$ &, $601^{\prime \prime}$ &, $351^{\prime}$ \\
& Sig. (2-tailed) & &, 000 &, 000 &, 030 \\
& $\mathrm{~N}$ & 38 & 38 & 38 & 38 \\
\hline Kepemimpinan & Pearson Correlation &, $583^{\prime \prime \prime}$ & 1 &, $448^{\prime \prime \prime}$ &, 038 \\
& Sig. (2-tailed) &, 000 & &, 005 &, 820 \\
& $\mathrm{~N}$ & 38 & 38 & 38 & 38 \\
\hline Perilaku_Produktif & Pearson Correlation &, $601^{\prime \prime \prime}$ &, $448^{\prime \prime \prime}$ & 1 &, $462^{\prime \prime \prime}$ \\
& Sig. (2-tailed) &, 000 &, 005 & &, 004 \\
& $\mathrm{~N}$ & 38 & 38 & 38 & 38 \\
\hline Kinerja & Pearson Correlation &, $351^{\prime \prime}$ &, 038 &, $462^{\prime \prime \prime}$ & 1 \\
& Sig. (2-tailed) &, 030 &, 820 &, 004 & \\
& $\mathrm{~N}$ & 38 & 38 & 38 & 38 \\
\hline
\end{tabular}

**. Correlation is significant at the 0.01 level (2-tailed).

*. Correlation is significant at the 0.05 level (2-tailed).

\section{Table 2. Indirect influence path coefficient}

Coefficients $^{\mathrm{a}}$

\begin{tabular}{|c|c|c|c|c|c|c|}
\hline \multirow[b]{2}{*}{ Mode } & & \multicolumn{2}{|c|}{ Unstandardized Coefficients } & \multirow{2}{*}{$\begin{array}{c}\begin{array}{c}\text { Standardized } \\
\text { Coefficients }\end{array} \\
\text { Beta }\end{array}$} & \multirow[b]{2}{*}{$t$} & \multirow[b]{2}{*}{ Sig. } \\
\hline & & $B$ & Std. Error & & & \\
\hline \multirow[t]{4}{*}{1} & (Constant) & 10,849 & 3,488 & & 3,110 &, 004 \\
\hline & Motivasi &, 130 &, 097 & .272 & 1,348 & , 187 \\
\hline & Kepemimpinan & -249 &, 141 & -318 & $-1,762$ &, 087 \\
\hline & Perilaku_Produktif &, 292 &, 121 &, 441 & 2,406 &, 022 \\
\hline
\end{tabular}

a. Dependent Variable: Kinerja

Based on tables 1 and 2, the model in the form of a path diagram as a result of testing the path coefficient is shown in Figure 1. 


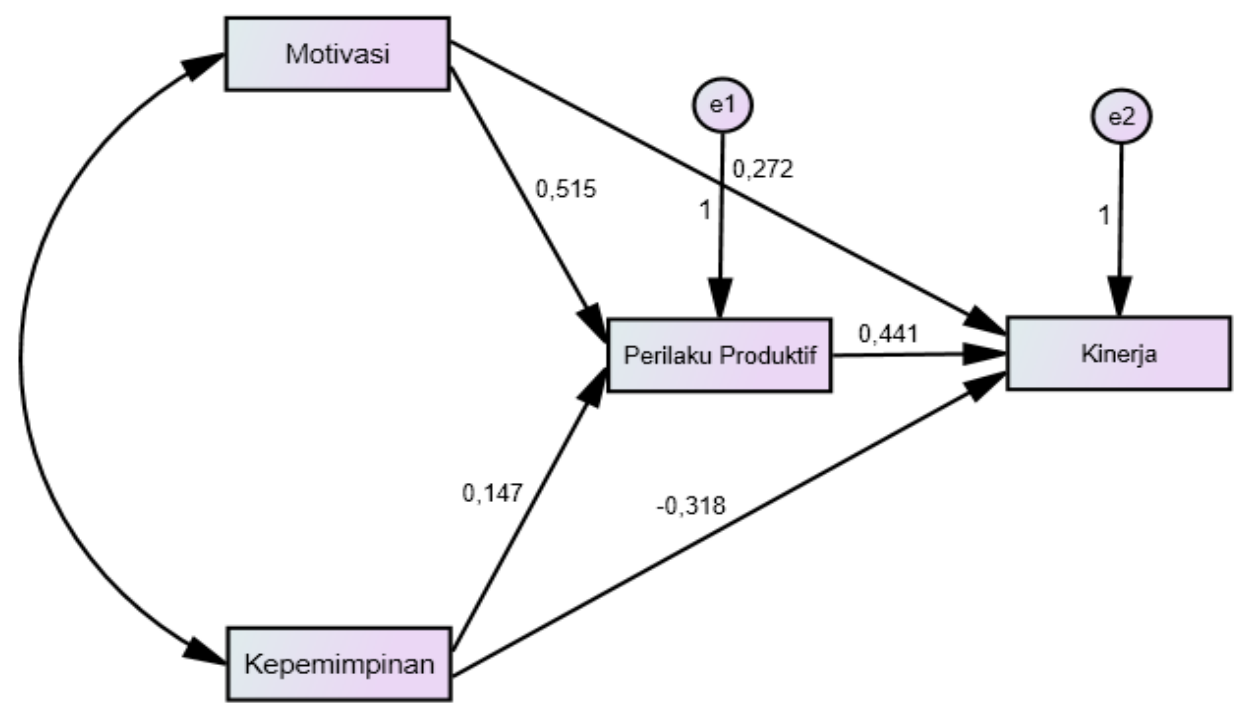

Figure 1. Path Analysis Result

$\mathrm{H} 1=\quad$ Motivation affects performance

$\mathrm{H} 2=$ Leadership affects performance

H3= Motivation affects performance through productive behavior

$\mathrm{H} 4=\quad$ Leadership affects performance through productive behavior

H5 = Productive behavior affects performance

H6= Leadership through productive behavior has an indirect influence on performance

\section{Interpretation}

\section{Motivation affects performance}

The results of data analysis in this study indicate that the existence of motivation has a significant effect on performance. This is indicated by the data correlations in SPSS that the effect of the motivation variable on performance is significant, because the probability (sig) is smaller than $\alpha(0.05)$ which is 0.003. According to ANOVA data in SPSS, the 0.009 ANOVA which is smaller than $\alpha(0.05)$ means that simultaneously between motivation, leadership and productive behavior have a significant effect on performance. Whereas according to the Coefficients data from SPSS that the motivation variable has no significant effect on performance because probability (sig) 0.187 is greater than $\alpha(0.05)$. The value of determination (Adjusted R Square) is 0.224 or $22.4 \%$. This value shows the magnitude of the influence of the motivation variable on performance by $22.4 \%$. This means that the magnitude of the influence of other variables (e2) is $100 \%-22.4 \%=77.6 \%$.

Thus, motivation has a significant effect on the performance of PNS teachers in Kalibaru State Vocational School.

\section{Leadership influences performance}

The results of this study indicate that the existence of leadership has a significant effect on performance. This is indicated by the data correlations in SPSS that the effect of leadership variables on performance is not significant because probability (sig) 0.820 is greater than $\alpha(0.05)$ which is 0.003 . According to ANOVA data in SPSS, the 0.009 ANOVA which is smaller than $\alpha(0.05)$ means that simultaneously between motivation, leadership and productive behavior have a significant effect on performance. Whereas according to the Coefficients data from SPSS that leadership variables have no significant effect on performance because the probability (sig) of 0.087 is greater than $\alpha(0.05)$. The value of determination (Adjusted R Square) is 0.224 or $22.4 \%$. This value shows the magnitude of the influence of the motivation variable on performance by $22.4 \%$. This means that the magnitude of the influence of other variables $(\mathrm{e} 2)$ is $100 \%-22.4 \%$. $=77.6 \%$.

Thus, leadership influences the performance of PNS teachers in Kalibaru State Vocational School. If the principal has good leadership, it can improve teacher performance. 


\section{Motivation affects performance through productive behavior}

The results of data analysis show that the existence of motivation has a significant effect on productive behavior. From the data correlations in SPSS, the effect of the motivation variable on productive behavior is significant because the probability (sig) of 0.000 is smaller than $\alpha(0.05)$. According to Anova data in SPSS, it shows ANOVA 0,000 which is smaller than $\alpha(0.05)$, which means that simultaneously between motivation, leadership has a significant effect on productive behavior. Whereas according to the Coefficients data from SPSS that the motivation variable has a significant effect on productive behavior because the probability (sig) 0.003 is greater than $\alpha(0.05)$. The influence of other variables is indicated by the value of determination (Adjusted $\mathrm{R}$ Square) is 0.34 or $34 \%$. This value shows the magnitude of the influence of the motivation variable on productive behavior by $34 \%$. This means that the magnitude of the influence of other variables (e1) is $100 \%-34 \%=66 \%$.

The results of this study are in accordance with the hypothesis that motivation influences productive behavior. This proves that motivation can provide high support in improving positive behavior for teachers in carrying out their work.

According to Yunus (2007), factors or indicators that can influence motivation towards positive behavior of teacher are security, opportunities to advance, type of work, good name of place to work, colleagues, wages, supervisors, working hours, working conditions. From those indicators, all PNS teachers at Kalibaru State Vocational School have given very good responses as indicated by the answers to the questionnaire answers that stated their agreement.

\section{Leadership affects performance through productive behavior}

The results of data analysis show that the existence of leadership has a significant effect on productive behavior. From the data correlations in SPSS, the effect of leadership variables on productive behavior is significant because the probability (sig) 0.005 is smaller than $\alpha(0.05)$.

Based on Anova data in SPSS, it shows ANOVA 0,000 which is smaller than $\alpha(0.05)$, which means that simultaneously between motivation, leadership and productive behavior have a significant effect on performance. Whereas according to Coefficients data from SPSS that leadership variables have no significant effect on productive behavior because probability (sig) is 0.377 greater than $\alpha(0.05)$. The influence of other variables is indicated by the value of determination (Adjusted R Square) is 0.34 or $34 \%$. This value shows the magnitude of the influence of the motivation variable on productive behavior by $34 \%$. This means that the magnitude of the influence of other variables $(\mathrm{e} 1)$ is $100 \%-34 \%=66 \%$.

The results of hypothesis testing indicate that leadership influences productive behavior to PNS teachers in Kalibaru State Vocational School.

From a number of indicators of leadership variables as well as productive behavior as outlined in the item items in the questionnaire as a whole shows a positive answer and agreement with the influence directly or indirectly.

\section{Productive behavior affects performance}

The results of data analysis in this study indicate that productive behavior has a significant effect on performance. This is indicated by data correlations in SPSS that the effect of productive behavior variables on performance is significant, because the probability (sig) 0.004 is smaller than $\alpha(0.05)$. According to ANOVA data in SPSS, the 0.009 ANOVA which is smaller than $\alpha(0.05)$ means that simultaneously between motivation, leadership and productive behavior have a significant effect on performance. The value of determination (Adjusted R Square) is 0.224 or $22.4 \%$. This value indicates the magnitude of the influence of the variable motivation on performance by $28.7 \%$. This means that the magnitude of the influence of other variables $(\mathrm{e} 2)$ is $100 \%-22.4 \%$. $=77.6 \%$.

\section{Direct and indirect influence}

Analysis of data obtained in this study purposed to determine the direct and indirect effects of the variable variables of this study. And the result is the motivation variable gives a direct influence on performance while the leadership variable also has a direct influence on the performance variable. The motivation variables and leadership variables through productive behavior indirectly affect performance. Besides that there are other variables influences on performance variables.

Motivational variables have a direct influence on productive behavior variables of 0.515 . The relationship of motivational variables with productive behavior variables is 0.601 . The leadership variable has a direct influence on the productive behavior variable of 0.147 . The relationship between leadership variables and productive behavior variables is 0.449 . Motivational variables and leadership variables simultaneously influence the productive behavior variable of 0.34 . The influence of other variables (e1) on productive behavior variables is 0.66 . Motivational variables have a direct influence on the performance 
variable of 0.272 . The relationship of the motivation variable with the performance variable is 0.351 . The leadership variable has a direct influence on the performance variable of -0.318 . Relationship of leadership variables with performance variables is as many as 0.038 . Productive behavior variables have a direct influence on the performance variable of 0.441 . The relationship of productive behavior variables with a performance variable is as many as 0.462 . Motivational variables, leadership and productive behavior variables simultaneously gave effect to the performance variable of 0.224 . The influence of other variables (e2) on the performance variable is 0.776 .

Motivational variable has an indirect influence on the performance variable through productive behavior variables of $0.515 \times 0.441=0.227$, because it is smaller than the direct relationship of motivation to performance that is 0.272 , the motivational relationship is stronger directly against performance than through productive behavior.

Leadership variable has an indirect influence on performance variables through productive behavior variable of $0.147 \times 0.441=0.065$, because when it is greater than the direct relationship of leadership to performance is $-0,318$, the leadership connection is stronger indirectly towards performance through productive behavior.

\section{Conclusion}

Based on the results of the study and description of the influence of motivation, leadership through productive behavior towards the performance of PNS teachers in Kalibaru State Vocational School, then according to each hypothesis, it can be concluded that: 1). Motivation affects performance. 2). Leadership affects performance. 3). Motivation affects performance through productive behavior. 4). Leadership affects performance through productive behavior. 5). Productive behavior affects performance. 6). Leadership through productive behavior has an indirect influence on the performance of PNS teachers in Kalibaru State Vocational School.

Motivation and leadership have significant influence on performance through productive behavior to PNS teachers in Kalibaru State Vocational School, so schools and principals are expected to do further improvement on services in the form of adequate learning equipment and appropriate infrastructure for PNS teachers

\section{Refrences}

Amirullah, 2015, Pengantar Manajemen, Mitra Wacana Media, Jakarta.

Agung Prihantoro, 2012, Pengaruh Motivasi, Disiplin, Lingkungan Kerja melalui Komitmen terhadap Kinerja Sumber Daya Manusia, Jurnal Value Added, Vol.8,No 2, Maret 2012-Agustus 2012

Azwar, Saifuddin, 2010. Reliabilitas dan Validitas, Pustaka Belajar, Yogyakarta.

Dharma, Agus, 2003. Manajemen supervisi, Raja Grafindo Persada, Jakarta.

Ghozali, Imam, 2005. Aplikasi analisis Multivariate dengan Program SPSS. Badan Penerbit Universitas Diponegoro.

Hariandja Marihot Tua, Efendi, 2007. Manajemen Sumber Daya Manusia, Penerbit Grasindo, Jakarta.

Hasibuan, Malayu S.P, 2009. Manajemen Sumber Daya Manusia, Edisi Revisi, Bumi Aksara, Jakarta.

Hisbullah Muhib, 2017, Pengaruh Motivasi, Reward dan Lingkungan Kerja terhadap Komitmen serta Dampaknya pada Kinerja,Tesis STIE Mandala Jember.

Istijanto, M. 2010. Riset Sumber Daya Manusia. Jakarta: PT Gramedia Pustaka Utama

Kuncoro, Mudrajat. 2007. Metode Kwantitatif. Yogyakarta : Unit Penerbitan dan Percetakan (UPP) STIP KYPN.

Lako, Adreas. 2004. Kepemimpinan dan kinerja Organisasi : Isu, Teori, dan Solusi. Cetakan Pertama. Penerbit Amara Books, Yogyakarta. 
Mangkunegara, Anwar, Prabu. 2009. Evaluasi Kinerja Sumber daya Manusia, PT. Rineka Aditama, Bandung.

Marsuhin, (2016), Pengaruh Kepemimpinan, Kedisiplinan dan Motivasi terhadap kinerja, Tesis STIE Mandala Jember.

Ni Made Oktaviani ,Ayu Desi Indrawati , 2014, Pengaruh Gaya Kepemimpinan,Kompensasi Finansial pada Kepuasan Kerja dan Kinerja Karyawan di CV. Wali Sukses Mandiri, Fakultas Ekonomi dan Bisnis Universitas Udayana.

P. Siagian, Sondang, 2004. Teori Motivasi dan Aplikasinya, Rineka Cipta, Jakarta.

Raden Rudi Alhempi ,2012. Pengaruh Kepemimpinan, Kometmen, Motivasi terhadap Kepuasan Kerja, Jurnal Media Riset Bisnis \& manajemen, Vo.12, No. 1, April 2012, pp. 58-80.

Riduwan, 2005. Dasar-Dasar Statistika, CV. Alfabeta, Bandung.

Robbins, Stephen. 2001. Perilaku Organisasi. Jakarta: PT. Prehellindo.

Sugiyono, 2007. Statistika untuk Penelitian, CV. Alfabeta, Bandung.

Suryani Dewi Pratiwi ( 2013 ), Pengaruh Motivasi, Kepuasan Kerja, dan Kepemimpinan, menuturt persepsi guru terhadap kinerja guru, Jurnal Pendidikan Insan Mandiri: Vol.1, No.1 (2013)

Wibowo. 2012. Manajemen Kerja. Yogyakarta. Edisi Ketiga. Jakarta: PT Raja Garafindo Persada

Widagdo, 2017. Manajemen Sumber Daya Manusia, Mandala Press, Jember.

Yuli Suwati , (2013), Pengaruh Kompensasi dan Motivasi Kerja terhadap Kinerja Karyawan Pada PT. Tunas Hijau Samarinda, Journal Ilmu Administrasi Bisnis, Volume 1, nomor 1, 2013:41-55 